\begin{tabular}{l} 
RCCS \\
\hline Annual Review
\end{tabular}

\section{RCCS Annual Review}

A selection from the Portuguese journal Revista Crítica de Ciências Sociais

$7 \mid 2015$

Issue no. 7

\title{
Strikes and Austerity in Portugal: Perspectives, Expression and Recomposition
}

Hermes Augusto Costa, Hugo Dias and José Soeiro

Translator. Sheena Caldwell

\section{OpenEdition}

Journals

\section{Electronic version}

URL: http://journals.openedition.org/rccsar/596

DOI: $10.4000 /$ rccsar.596

ISSN: $1647-3175$

\section{Publisher}

Centro de Estudos Sociais da Universidade de Coimbra

\section{Electronic reference}

Hermes Augusto Costa, Hugo Dias and José Soeiro, « Strikes and Austerity in Portugal: Perspectives, Expression and Recomposition ", RCCS Annual Review [Online], 7| 2015, Online since 01 October 2015, connection on 19 April 2019. URL : http://journals.openedition.org/rccsar/596; DOI : 10.4000/ rccsar.596 


\title{
Hermes Augusto Costa
}

School of Economics and Centre for Social Studies, University of Coimbra, Portugal

\section{Hugo Dias}

Centre for Studies in Trade Unionism and Labour Economics, University of Campinas (CESIT-UNICAMP), Brazil

\section{José Soeiro}

School of Economics and Centre for Social Studies, University of Coimbra, Portugal

\section{Strikes and Austerity in Portugal: Perspectives, Expression and Recomposition*}

\begin{abstract}
Against the background of worsening employment conditions and increasing imbalances in labour relations, this text discusses the importance of the strike phenomenon in the context of austerity. The first section presents some sociological perspectives on strikes, specifically those relating to notions of democracy and socio-legal regulation, ideology/ies and tensions between collective and individual action, issues of scale and controversies, and timing and outcomes. The second part adopts a quantitative approach and seeks to determine whether the theoretical potential for conflict can be verified in concrete terms. Finally, it discusses the experience of a strike by workers in a specific precarious sector (employees at the "Saúde 24" medical helpline), which provides scope for an assessment of the challenges facing trade union activity and reflections on new ways of organising social conflict.
\end{abstract}

Keywords: austerity; workers' rights; strikes; labour market; precarious employment.

\section{Introduction}

The scenario of austerity which has hit the periphery of the eurozone in recent years is associated with phenomena such as unemployment, precarious employment, inequality, poverty and conflict (Standing, 2011; Campos Lima and Artiles, 2011; Costa, 2012a; Santos, 2012; Ferreira, 2012; Estanque, 2013; Estanque, Costa and Soeiro, 2013). Taking the situation in Portugal as a reference, this text aims to identify the place of conflict, more precisely strikes, within the context of austerity. It is our belief that the potential for contestation is significant, since employment and social rights, which extend far beyond the socio-professional sphere and affect people's lives, are being threatened. Nevertheless, in apparent contrast to the increasing number of reasons for protest, it is difficult nowadays to mobilise the "strike weapon," especially since austerity has the effect of making workers fear that more protests may mean an increasing risk of job losses. Moreover, the growing informalisation and decontractualization of labour relations, accentuated by successive policy measures and reforms, poses challenges and difficulties to the use of this instrument.

\footnotetext{
* A slightly different version of this article was published in Portuguese in RCCS 103 (May 2014). DOI: $10.4000 /$ rccs.5584
} 
In the case of Portugal, the austerity resulting from the Memorandum of Understanding signed in May 2011 by the Portuguese government and the Troika - the International Monetary Fund (IMF), European Central Bank (ECB) and European Commission (EC) together with the actions taken by the Portuguese government, is reflected in the labour law in force since August 2012 (Law 23/2012). These measures can be very briefly summarised as follows: greater concessions to companies concerning the choice of whom to dismiss in the event of redundancies; more comprehensive grounds for dismissal due to inadaptability; cuts in overtime; individually negotiated hour bank systems; reductions in severance payments; fewer holidays; cuts to public holidays; the possibility of closing companies on days that fall between a weekend and a public holiday; changes to the system regulating absences from work; fewer obligations regarding labour inspection; the possibility of working six consecutive hours (Costa, 2012b; Leite et al, 2013).

These reforms appear to show that austerity is reinforcing the asymmetries in labour relations and heavily penalising the "labour factor." This is reflected not only in an increase in precarious forms of employment - representing approximately $30 \%$ of employment as a whole and particularly prevalent amongst the 15-34 age group, where the figures approach 50\% (Estanque and Costa, 2012) - but also in the numbers of unemployed, which in June 2013 totalled $17.4 \%$ (12.1\% in the eurozone and $10.9 \%$ in the EU-27), although this later fell to $15.4 \%$ in December 2013 (12.1\% in the eurozone and $10.9 \%$ in the EU/28) (Eurostat, 2014). ${ }^{1}$

In addition, other worrying signs for labour relations are emerging from the austerity measures: the loss of autonomy of social partners, especially trade unions, which have seen their position further undermined; greater tensions in relations between the actors involved in labour relations (including within the union movement); the reinforcement of asymmetries in the labour market, namely between high income and low income categories, or in relations between the public and the private sector; a sharp fall in the purchasing power of households; greater impoverishment of the productive sector; failure to tackle the lack of competitiveness of companies; less control for the Autoridade para as Condições de Trabalho (ACT - the Authority for Working Conditions), since companies are no longer

\footnotetext{
${ }^{1}$ Nevertheless, it is important to recall that the number of people of working age who have left the country, together with an increase in those discouraged, i.e. who have actively given up looking for work, also helps to explain the upturn in employment figures in the final quarter of 2013.
} 
obliged to send timetables or agreements on exemption from fixed working hours to the ACT; etc. (Fernandes, 2012; Rebelo, 2012; Gomes, 2012; Costa, 2012b; Leite et al., 2013).

Within this context, what is the role and importance of the strike and what forms does it take? Although strikes function as the main expression of conflict, the results of trade union demands (as expressed through strikes, for example) tend to take a long time to emerge, and this is even more evident in a context of crisis and recession (Hyman, 2012). Equally, "the frequency of strikes and the involvement of workers in them is more a measure of conflict within a system of industrial relations than of trade union power, and they should only be used cautiously and in conjunction with a consideration of other variables as a measure of union capacity to mobilise" (Stoleroff, 2013: 231).

Taking these observations into consideration, this text is divided into three parts. The first section presents some sociological perspectives and analytical cross-referencing on strikes. The second part adopts a quantitative approach and seeks to determine whether the theoretical potential for conflict can be verified in concrete terms. Finally, it discusses the experience of a strike by workers in a specific precarious sector - employees at the "Linha Saúde 24" medical helpline - which provides scope for an assessment of the challenges facing trade union activity and reflections on new ways of organising social conflict.

\section{Sociological Perspectives on Strikes}

A sociological analysis of strikes in the context of austerity (but not only austerity) may incorporate various perspectives and, consequently, various connections.

a) Strikes, democracy and socio-legal regulation. More than half a century ago, Lewis Coser (1956), in a combined analysis of conflict and social structure, considered it necessary to distinguish between conflicts according to whether they took place in democratic or authoritarian societies. If a conflict occurs in a democratic society it will tend to be tolerated, which essentially means that, as a democratic right, the right to strike was (and is) associated with the idea of "freedom of association" (IUR, 2013: 2). However, if it takes place in an authoritarian society, the conflict will either be banned or severely repressed.

The five general strikes that took place in Portugal between November 2010 and June 2013 therefore showed that exercising the right to strike in a democratic context is recognised as a basic right and has been increasingly integrated into the various forms of social regulation. Moreover, the idea of the "institutionalisation of conflicts" (Dahrendorf, 
1981) or "safety valves" (Coser, 1956) is, to a certain extent, embodied in the idea of "notice of strike." In other words, in a democratic context, strikes are regulated in a positive way in order to accommodate the opposing parties and avoid fatally compromising relations between them from the outset. In fact, a dual rejection is associated with this idea of positive social regulation, namely that lasting solutions can be found for all conflicts, and that conflicts are resolved with more conflict/repression. Hence the presuppositions for positively controlling disputes: i) the inevitability of conflict; ii) the idea that this inevitability does not signify resignation; iii) the importance of recognising the differences between the parties involved (government-unions; unions-bosses, etc.); iv) the idea that the organisations involved represent the actual interests of their members; v) the fundamental importance of defining procedural rules which help to reduce differences (Dahrendorf, 1981). In the case of Portugal, the definition of "minimum services," although it may not be consensual and may depend on the rulings of the arbitration bodies, also appears to lead towards a compromise regulated by a minimum level of accommodation and integration of the parties involved (and society as a whole) in terms of anticipating/preparing for a strike, irrespective of the gains and losses that may result for those involved.

Nowadays, however, it appears that the dynamics of austerity and increasingly precarious employment relations not only mean that strike action is being curbed due to fear, but also that striking may emerge as a "wildcat" act that is not recognised legally, as the case study in this article shows. In a context of "de-democratisation of democracy" (Rosas, 2012), situations in which exercising the right to strike fall outside the sphere of social regulation are on the increase, since employment itself is increasingly operating outside contractual norms.

b) Ideology(ies), collective action and individual conscience. It may be said that strikes are not neutral, given that they are influenced by the ideological orientations of the trade union organisations which organise them. João Freire (2001), for example, associates the capacity of trade unions to mobilise their members with a set of ideologies: the reformist ideology, also known as Labour, Nordic, Anglo-Saxon or democratic, characterised by its defence of the immediate interests of workers and reforms to society and the state that will lead to greater democracy, operating in conjunction with the socialist parties; the revolutionary syndicalist ideology, characterised by anarchist or libertarian ideas, which rejects the role of political parties and proposes the trade union movement as an agent for radical change in 
capitalist societies; the bolshevist ideology, theorised on the basis of the 1917 Russian Revolution, inaugurating a new way of linking union organisation to the vanguard political party, which became known as the "transmission belt."

Converging or similar ideologies therefore provide the conditions for consistent collective action, although austerity policies (also ideologically orientated) have had the effect of bringing together union organisations with different ideologies, albeit sometimes only circumstantially. In other words, austerity has led to the development of links based on concrete interests, creating moments when different ideologies and union tendencies unite against the ideology of the government. This was the case, for example, with the three general strikes jointly organised by the Confederação Geral dos Trabalhadores Portugueses (CGTP - General Confederation of Portuguese Workers) and the União Geral de Trabalhadores (UGT - General Union of Workers), two organisations with conflicting ideological tendencies. It resulted in the general strikes of 24 November 2010 (in protest against announced cuts of $3.5 \%$ to $10 \%$, from January 2011, to the salaries of civil servants earning over 1,500 euros), 24 November 2011 (against cuts in holiday and Christmas pay for civil servants in 2012, as well as the 50\% surtax on Christmas pay), and 27 June 2013 (in response to the cuts envisaged in the Budget Strategy Document, and therefore the measures associated with the reform of the state: a retirement age of 66; public sector working hours increased from 35 to 40 hours per week; reduced holidays; higher civil servants' health insurance contributions; the loss of 30,000 public sector posts; the special mobility scheme, etc.). Nevertheless, on other occasions the tensions between the union confederations were evident. $^{2}$

Yet, even though collective action may "trump" ideology, the decision to go on strike is still an individual decision. Although the call for a strike results from a collectively mandated decision based on a consensus provided by the members of a particular trade union association rather than just its governing body, the choice of whether to join the strike or not is ultimately the responsibility of each individual citizen. Referring to the paradox of

\footnotetext{
${ }^{2}$ This occurred twice in 2012 alone, with the general strike of 22 May 2012 called by the CGTP in response to the signing of an agreement on social dialogue (entitled Commitment to growth and employment) by the government, employers' confederations and the UGT on 18 January 2012, and with the general strike of 14 November 2012, an Iberian trade union strike organised by the European Trade Union Confederation (ETUC), which, although it was only called by the CGTP in Portugal, involved the ETUC and 30 other UGT unions. In Portugal, this general strike also emerged as a protest against the proposed State Budget for 2013, which implied harsh tax increases.
} 
collective action, Mancur Olson (1965) considers that the mobilisation of individual actors for the purpose of obtaining collective benefits (for example, a benefit that is of interest to the whole group and which no member of the group is barred from enjoying) is subject to the reasoning (and self-interest) of individual actors. Thus, whenever an individual hesitates to go on strike because they are incapable of "overcoming fear" (Silva, 2012), since striking ultimately means a loss of earnings and may also mean losing one's job, they are not necessarily against the collective act of going on strike but are weighing up their own interests. This tension clearly emerges in the case study that will be analysed later.

c) Scale, controversies and types. Strikes most commonly take place on a national scale, i.e. the level on which salaries, working conditions and jurisdiction are defined and are therefore open to disagreement and contestation. It is a level that is not immune to public controversy, generally involving those who question the occasion to strike and/or doubt its effectiveness and those who believe that rejecting the present struggle means sanctioning a regression imposed by government policies. At times the focus of the controversy even has the effect of recentring the analysis of the conflict and compromising the ongoing discussion, when there are accusations (on both sides) that the focus of the conflict is being distorted and is harming third parties (namely the idea that a strike by teachers during the examination period is damaging to students, who have nothing to do with the situation, or that patients are the main "victims" of a nurses' strike). The reverse situation is also admissible, when the supposed harm for some may mean benefits for others: a strike by public transport workers, for example, may penalise those who use these services and at the same time benefit taxi drivers who may gain more customers.

Given that the media and the public arena are still predominantly structured on a national level (primarily because of language and the connection with national political communities), a transnational strike (involving various countries and trade union structures) would certainly have another kind of visibility and impact. However, within a European and world context, it is rare to speak about a "European/world strike" (Costa, 2008; 2010). ${ }^{3}$ Even though in the Viking and Laval cases the Court of Justice of the European Union explicitly recognised the right to strike as a fundamental right protected by EU and international legislation (by the standards of the International Labour Organization), the interpretation of

\footnotetext{
${ }^{3}$ Nevertheless, it is worth noting the growing importance of world protests, in which "anti-austerity" plays a leading role (Ortiz et al., 2013).
} 
how this right could be exercised within the internal European market ultimately gave priority to fundamental economic freedoms. In effect, the right to strike was seen as a restriction on economic freedoms that could only be justified in individual cases, interpreted within a strict framework of conditionality and proportionality (Bruun, 2013: 8; Giubboni and O’Brien, 2009: 9-10).

In addition to scale and controversies, as well as the related socio-legal obstacles - which sometimes indicate a certain marginalisation of strikes (Giraud, 2005) - it is important to identify types of strike. Reference has already been made to the idea of the "general strike," which is supposed to unite the protests of the whole of society. However, it is also important to mention sectoral strikes (such as strikes in the transport sector, which is very directly affected both by wage cuts and privatisation) or those organised by socio-professional categories affected by austerity (such as teachers or nurses). Very often these sectoral and socio-professional protests have national, countrywide scope as, for example, in the case of the teachers' strike during the assessment and exam period in response to the increase in the public sector working hours (from 35 to 40 per week) and the mobility (requalification) scheme. However, "partial strikes" have also been common in Portugal in the past three years, an option which can partly be explained as a means of not weighing too heavily on the pockets of those who strike, particularly as there is no tradition of "strike funds" in Portugal. ${ }^{4}$

The relationship between the public and private sector is also reflected in the different types of strikes. When a strike is said to be "general," it is assumed to cover both the public and the private sector. It may be said that the act of going on strike traditionally involves a greater feeling of fear and insecurity amongst those who work in the private sector as opposed to the public sector which, according to a study by Rebelo and Brites (2012: 74), also partly explains why a larger percentage of those who go on strike $(40.1 \%)$ work in public administration. However, since public employees have been severely hit by austerity measures, it is not surprising that the fear of losing state employment is accompanied by a fear of taking part in strikes.

d) Temporalities and results. The temporal aspect of strikes includes not only the period "before" but also the "during" and "after" periods. The extent to which the objectives of a

\footnotetext{
${ }^{4}$ This practice is more common in the Scandinavian and German unions, whereas in Portugal only a few unions (such as the train drivers union, for example) resort to it. One plausible explanation for this concerns economic reasons (the low wages in Portugal make it unfeasible for workers to pay an extra quota on top of the monthly dues already paid to the union).
} 
strike are defined brings us to the reasons for justifying a strike. Returning to Lewis Coser (1956), a tension sometimes exists between achievable and unachievable objectives, and strike action (whether in the "during" or "after" stages) is guided by this tension. According to Coser, when conflicts are realistic, i.e., based on achievable results, it is possible to define alternative means to reach certain goals. On the other hand, when the conflict is based on objectives that are unachievable, the relationship between the antagonists tends to become radicalised and may even involve emotional reactions, in the form of personal attacks.

The duration of a strike translates into the strike as it happens. In Portugal one-day campaigns are common (as in the case of general strikes), although they may also extend to a week or two weeks, depending on the sector of activity. Since, as previously mentioned, there is no tradition of "strike funds" in Portugal, strikes which last longer may depend on the capacity of those involved to "bear" the conflict. ${ }^{5}$

However, the "post-strike" (or "afterwards") is perhaps the most important moment in the concept of the strike as a process, in the sense that it indicates the impact, effectiveness and outcomes and therefore allows for an assessment of the extent to which the objectives were achieved. In fact, as the essence of trade union power (IUR, 2013: 2), exercising the right to strike over many decades has translated into multiple achievements and advances, both from the point of view of working conditions (reductions in working hours, the work/life balance, the defence of jobs, the ban on unfair dismissal) and financial benefits (the establishment of the national minimum wage; substantial pay rises; one month of paid holidays, with the respective subsidy; the $13^{\text {th }}$ and $14^{\text {th }}$ month bonuses), etc. Essentially, it is a matter of acting "against the tide" and "acting for change" (Silva, 2002) with the aim of “obtaining benefits and concessions" (Dias, 2012: 114).

Although the next section considers the quantitative expression of strikes, the results cannot be measured by quantitative criteria alone, based on the simple answer to the question "what was the turnout?" Although the answer is clearly essential - particularly if it is used to measure the immediate impact of the strike - it is no less true that this yardstick is

\footnotetext{
${ }^{5}$ In June 2013 the strike by secondary school teachers was called for a two-week period, which obliged the teachers to organise, in order not to suffer further wage losses, by contributing to an "operating fund." From amongst the teachers who stated they were willing to go on strike, it was agreed that at least one teacher would be absent from class committee meetings dedicated to assessing students, which would made it impossible for the meetings to be held. Therefore, making use of the operating fund (to which each striking teacher contributed 10 euros, but also included contributions from some who were not on strike), teachers who took part in the strike received a "solidarity payment" that minimised their loss of earnings at the end of the month (Diário de Notícias, 13.03.2013).
} 
open to various forms of bias and tension in political and technical arguments involving the opposing parties. We therefore believe that a strike may produce results that extend beyond the immediate impacts, since the actual controversies surrounding the "effectiveness" or the "innocuous" nature of strikes are not resolved the following day (Estanque, 2010). Essentially, the results of strikes must be analysed in the light of the extent to which objectives are achieved (by both sides), which may unfold in the short, medium or long term (Costa, 2011).

The fact that in many situations an idea of the immediately achieved objectives/results is not transmitted to the public may lead to a certain lack of faith in the strike as a weapon in the medium/long term. Returning to the study by Rebelo and Brites (2012: 75-77), the following appears in response to the question "What results were obtained the last time you went on strike?": 51.5\% (of the 369 respondents) answered "none"; $32.5 \%$ said there had been "partial" results; and only $6.5 \%$ stated that they were entirely satisfied and had achieved "total" results. This pragmatic and not very optimistic view of the effectiveness of strikes even infects the discourse of union leaders who are less accustomed to placing strikes at the forefront of negotiations. ${ }^{6}$ This may also be seen, not only as recovering the ideological bias reflected in trade unionist discourse, but also as one more reflection of the negative effects of austerity policies.

\section{Strikes: Quantitative Expression}

As already noted, strikes are part of the historical repertoire of collective trade union action. However, a strike, in itself, is not an indicator of trade union strength or mobilisation capacity. Trade union power is, in fact,

determined by the capacity of union organisations (confederations and sectoral or local structures) to mobilise various types of resources and fully or partially realise their objectives. Thus, the concept is composed as much of quantitative as qualitative indicators, and refers inter alia to organisational resources, namely union membership, the development of the union organisation, the influence unions may have on political parties and the state, as well as their allies, in addition to the capacity to mobilise on the part of union members and other workers, the negotiating power of unions and the level of institutionalisation achieved by unions within a system of socio-economic regulation in which the extent/coverage and effectiveness of collective bargaining and dialogue play an important part. (Stoleroff, 2013: 224).

\footnotetext{
"In fact, the current leader of the UGT has more than once alluded in public to the "Greek situation" to support the idea that, although over twenty general strikes have taken place there in the last 3-4 years, they have produced no concrete results.
} 
Union power is based on unionisation or, in other words, the absolute number of members of a union, as well as trade union density in a given sector (the coefficient between the number of union members and salaried workers in the same sector). These are key elements in determining the representativeness and influence of unions in the field of collective labour relations, their relationship with other social and political actors, and also with society in general (Pedersini, 2010). Even though unionisation is not the only criterion that can be used to determine the social influence of trade unions, it is one of the key resources (Sousa, 2011: 5), since organisational strength depends on the capacity to involve the largest possible number of members in the everyday work of the organisation and represent it in a wide variety of ways, as well as on pursuing its aims by mobilising and winning over the support of workers in general. The dues paid by members are obviously the main source of income for trade union organisations, which depend on this to provide the means and resources necessary for their work. This is even more important in countries such as Portugal where there is no form of government aid for unions.

Although there is no causal relationship between union membership and the number of strikes, the former favours greater collective mobilisation and, as such, the potential use of strikes. We will therefore first reconstitute, on the basis of the available information, a longterm statistical series for strikes in Portugal, together with trade union density, an indicator of union strength. Following this, the analysis will concentrate on the most recent period, from 2007 onwards, with the aim of determining whether there has been an increase in the number of official strikes, ${ }^{7}$ the sectors which have mobilised most, their "campaign agendas" and their effectiveness.

\footnotetext{
${ }^{7}$ Strikes are called under the terms of Articles 530 to 543 of the Labour Code. For statistical purposes, "in its broadest sense a strike is considered to be abstention from, or temporary and planned disruption of, the normal terms under which work is carried out, by a group of workers with the aim of forcing the employer or public authority to accept their demands" (GEE/Ministério da Economia, 2011). However, the available data only includes stoppages during normal working hours. It does not include other types of strikes involving overtime and extra hours, although information is gathered on this (GEP/MTSS, 2008).
} 
Table 1. Union Membership and Strikes in Portugal: 1974-2013

\begin{tabular}{|c|c|c|c|c|}
\hline Year & $\begin{array}{l}\text { No. members } \\
\text { (thousands) }\end{array}$ & Union density (\%) & No. strikes & $\begin{array}{l}\text { No. workers on } \\
\text { strike (thousands) }\end{array}$ \\
\hline 1974 & --- & --- & 313 & --- \\
\hline 1975 & --- & --- & 340 & --- \\
\hline 1976 & --- & --- & 367 & --- \\
\hline 1977 & --- & --- & 357 & --- \\
\hline 1978 & $1,486.8$ & 60.8 & 333 & --- \\
\hline 1979 & 1,500 & 60.1 & 381 & --- \\
\hline 1980 & 1,460 & 54.8 & 374 & --- \\
\hline 1981 & 1,420 & 53.5 & 756 & --- \\
\hline 1982 & 1,380 & 50.5 & 563 & --- \\
\hline 1983 & 1,340 & 47.2 & 532 & --- \\
\hline 1984 & 1,300 & 47.2 & 550 & --- \\
\hline 1985 & 1,225 & 44.6 & 504 & --- \\
\hline $1986^{8}$ & 1,150 & 41.2 & 363 & 231.5 \\
\hline 1987 & 1,093 & 38.6 & 213 & 81.3 \\
\hline 1988 & 1,035 & 35 & 181 & 155.5 \\
\hline 1989 & 978 & 32 & 307 & 296.1 \\
\hline 1990 & 920 & 28 & 271 & 128.9 \\
\hline 1991 & 896 & 28.2 & 262 & 119.1 \\
\hline 1992 & 872 & 26.1 & 409 & 131.9 \\
\hline 1993 & 848 & 26.1 & 230 & 83.1 \\
\hline 1994 & 824 & 25.9 & 300 & 94.4 \\
\hline $1995^{9}$ & 800 & 25.4 & 282 & 60.4 \\
\hline 1996 & 802.6 & 25.5 & 272 & 50.5 \\
\hline 1997 & 805.1 & 25.2 & 265 & 45.8 \\
\hline 1998 & 798 & 23.4 & 227 & 44.2 \\
\hline 1999 & 790 & 22.5 & 200 & 33.5 \\
\hline 2000 & 783 & 21.6 & 250 & 38.8 \\
\hline 2001 & 824 & 22.4 & 208 & 26.1 \\
\hline 2002 & 768 & 20.7 & 250 & 80.2 \\
\hline 2003 & 783.4 & 21.2 & 170 & 30.3 \\
\hline 2004 & 802.6 & 21.4 & 122 & 31.9 \\
\hline 2005 & 804.2 & 21.2 & 126 & 21.7 \\
\hline
\end{tabular}

\footnotetext{
${ }^{8}$ From 1986 the chronological series covers all sectors of economic activity with the exception of public administration (GEP/MTSS, 2008).

${ }^{9}$ From 1995 the chronological series covers mainland Portugal and the Autonomous Regions (GEP/MTSS, 2008).
} 


\begin{tabular}{|c|r|r|r|r|}
\hline $\mathbf{2 0 0 6}$ & 805.9 & 20.8 & 155 & 33.5 \\
\hline $\mathbf{2 0 0 7}$ & 804.4 & 20.8 & 99 & 29.2 \\
\hline $\mathbf{2 0 0 \mathbf { 1 0 } ^ { \mathbf { 1 0 } }}$ & $\mathbf{8 0 3}$ & 20.5 & --- & -- \\
\hline $\mathbf{2 0 0 9}$ & 771 & 20.1 & --- & --- \\
\hline $\mathbf{2 0 1 0}$ & 738 & 19.3 & 131 & 72.3 \\
\hline $\mathbf{2 0 1 1}$ & 694 & 19.5 & 106 & 59 \\
\hline $\mathbf{2 0 1 2}$ & 665 & 20.5 & 147 & 93.1 \\
\hline $\mathbf{2 0 1 3}$ & --- & --- & 136 & 71.1 \\
\hline
\end{tabular}

Sources: GEP/MTSS, 2008; GEE/Ministério da Economia, 2011, 2012, 2013, 2014; ICTWSS, 2013 Observatório do Emprego e Formação Profissional, Região Autónoma dos Açores (2011, 2012, 2013, 2014); OECD (2015); Secretaria Geral da Educação e Recursos Humanos, Região Autónoma da Madeira (2014, 2015); Stoleroff (2013).

An analysis of Table 1 reveals a long-term downward trend in the indicators for trade union membership and density and strike statistics, despite some periods of upturn or levelling off.

The period when unions had the greatest capacity for mobilisation and collective action, under the influence of a class-based discourse advocating the overthrow of capitalism, was during the second half of the 1970s, when tripartite collective bargaining was the norm in Europe (Santos, 2004: 161-162). The figures for union membership and trade union density were at their highest $(60.8 \%$ in 1978), partly a legacy of the obligatory unionisation of the Estado Novo, and the number of strikes was also high (367 in 1976). In the mid 1980s, union membership gradually began to decline, whilst the figures for strike activity were high (756 strikes in 1981). Up to the beginning of the 1980s, campaigns were pursued to establish collective bargaining, a process which continued throughout the early 1980s and which, although less intensive, remained contentious. From the start of the 1980 s until 1985 , strikes expressed the struggle to defend the "achievements of the April Revolution" and destabilise right-wing and central bloc governments (Stoleroff, 2013: 231).

With regard to union membership, following a sharp fall in the 1980 s (from $54.8 \%$ in 1980 to $32 \%$ in 1989), the downturn continued throughout the 1990 s, although it was less marked. This process also involved a change in the sociological composition of union members. Parallel to the shrinking industrial sectors, there was an increase in the number of workers employed in the service sector, specifically in local and central government posts

\footnotetext{
10 No statistics were produced for 2008 and 2009, due to insufficient information (GEE/ Ministério da Economia, 2011). However, data is available for the Autonomous Regions of the Azores and Madeira.
} 
(MTSS, 2006: 68), which prevented a sharper fall in union membership. In the 2000s the figures remained steady at slightly over $20 \%$, dipping below this to $19.3 \%$ in 2010 . However, the data for more recent years present apparently contradictory signs. Whereas, on the one hand, they reveal a surprising upturn in trade union density (19.5\% in 2011 and 20.5\% in 2012), on the other, the figures for union membership fell to 694,000 (in 2011) and 665,000 (in 2012), in line with the trend for previous years, which we believe is the scenario closest to the reality of the situation. It is also necessary to take into account the fact that the working population has decreased significantly, which means that even a slight rise in the rates of union membership could be explained by the fact that jobs are being lost at a faster pace than the fall in the absolute figures for union membership.

The date for Portugal's entry into the European Economic Community, which roughly coincides with the institutionalisation of collective bargaining involving the trade unions, marks the beginning of a strong downward trend in the number of strikes (which only showed an upturn in 1989, when 307 strikes were held, involving 296,000 strikers), reaching a historic low of 99 strikes in 2007, involving approximately 29,200 workers.

Within this context, one hypothesis that can be explored concerns the possibility that this downward trend has been reversed recently, even if only temporarily, due to the expression - albeit not the only expression but certainly a relevant one - of the socio-labour conflict surrounding the measures implemented under successive austerity packages. The absence of data for 2008 and 2009 means that it is not possible to follow this development throughout the recent period when the international financial crisis was already beginning to have a contagious effect on sovereign debts, and budget restraint measures and changes in labour regulation were beginning to be felt in countries such as Portugal.

Thus, if we take into consideration the information available for the years 2010, 2011, 2012 and 2013, an upturn in the minimum figures for both the number of strikes and the number of workers on strike can, in fact, be observed. In 2010, the number of workers on strike rose by approximately 72,300 in comparison to 2007; in 2011 it fell to around 59,000, although a sharp rise can be observed in 2012, when the annual total was approximately 93,100, the highest figure since 1994. This was followed by a fall in 2013 to around 70,100, which was still well above the historic minimum levels recorded prior to 2008.

It should first be noted that five general strikes were called by the CGTP during this period (2010-2013), three of which were held jointly with the UGT, with notices of strike that 
covered all sectors of economic activity. Secondly, as Table 2 shows, the sectors with the highest strike activity are, in terms of absolute numbers and in ascending order, those dedicated to health and social work $(2010$ - 6,949; 2011 - 6,822; 2012 - 14,342; 2013 17,135), manufacturing and processing industries (2010 - 22,802; 2011 - 14,781; 2012 $21,875 ; 2013-12,309)$ and transport and storage (2010 - 26,189; $2011-21,193 ; 2012-$ $35,519 ; 2013-31,375)$. If we consider the criterion of the number of workers on strike per 1,000 salaried workers, the transport and storage sector clearly stands out, with 204.2 in 2010, 168 in 2011, 281 in 2012, and 265 in 2013.

Table 2. Strikes by Sector, 2010-2013 ${ }^{11}$

\begin{tabular}{|c|c|c|c|c|c|c|c|c|c|c|c|c|}
\hline \multirow[t]{2}{*}{$\begin{array}{c}\text { CAE/ } \\
\text { Rev. } 3^{12}\end{array}$} & \multicolumn{3}{|c|}{2010} & \multicolumn{3}{|c|}{2011} & \multicolumn{3}{|c|}{2012} & \multicolumn{3}{|c|}{2013} \\
\hline & $\begin{array}{c}\text { No. } \\
\text { strikes }\end{array}$ & $\begin{array}{c}\text { No. } \\
\text { workers }\end{array}$ & $\begin{array}{c}\text { Workers } \\
\text { on strike, } \\
\text { per } 1,000 \\
\text { sW* }\end{array}$ & $\begin{array}{c}\text { No. } \\
\text { strikes }\end{array}$ & $\begin{array}{c}\text { No. } \\
\text { workers }\end{array}$ & $\begin{array}{c}\text { Workers } \\
\text { on strike, } \\
\text { per } 1,000 \\
\text { sW* }\end{array}$ & $\begin{array}{c}\text { No. } \\
\text { strikes }\end{array}$ & $\begin{array}{c}\text { No. } \\
\text { workers }\end{array}$ & $\begin{array}{c}\text { Workers } \\
\text { on strike, } \\
\text { per } 1,000 \\
\text { sW }^{*}\end{array}$ & $\begin{array}{l}\text { No. } \\
\text { strikes }\end{array}$ & $\begin{array}{c}\text { No. } \\
\text { workers }\end{array}$ & $\begin{array}{c}\text { Workers on } \\
\text { strike, per } \\
1,000 \text { SW* }\end{array}$ \\
\hline Total & 123 & 70,792 & 27.3 & 88 & 58,413 & 23 & 127 & 92,324 & 36 & 119 & 70,405 & 30 \\
\hline $\begin{array}{l}\text { A - } \\
\text { Agriculture, } \\
\text { hunting, } \\
\text { forestry \& } \\
\text { fishing }\end{array}$ & 1 & 224 & 4.6 & 1 & 87 & 2 & 3 & 265 & 5 & 1 & 139 & 3 \\
\hline $\begin{array}{l}\text { B - Mining \& } \\
\text { quarrying }\end{array}$ & 5 & 515 & 52.3 & 2 & 68 & 7 & 3 & 92 & 10 & 2 & 150 & 18 \\
\hline $\begin{array}{l}\text { C- } \\
\text { Manufacturi } \\
\text { ng \& } \\
\text { processing }\end{array}$ & 55 & 22,802 & 39.5 & 31 & 14,781 & 26 & 50 & 21,875 & 39 & 23 & 12,309 & 23 \\
\hline $\begin{array}{l}\text { D - } \\
\text { Electricity, } \\
\text { gas, steam \& } \\
\text { water }\end{array}$ & 4 & 665 & 90.2 & 4 & 529 & 74 & 5 & 613 & 86 & 2 & 205 & 30 \\
\hline $\begin{array}{l}\text { E- } \\
\text { Collection, } \\
\text { purification } \\
\& \\
\text { distribution } \\
\text { of water }\end{array}$ & 6 & 1,199 & 61.2 & 5 & 992 & 50 & 4 & 1,343 & 67 & 5 & 891 & 45 \\
\hline $\begin{array}{l}\mathrm{F}- \\
\text { Construction }\end{array}$ & 6 & 321 & 1.2 & 4 & 257 & 1 & 3 & 209 & 1 & 4 & 371 & 2 \\
\hline $\begin{array}{l}\text { G- } \\
\text { Wholesale \& } \\
\text { retail trade }\end{array}$ & 16 & 2,069 & 4.1 & 9 & 2412 & 5 & 17 & 2,933 & 6 & 12 & 1,788 & 4 \\
\hline
\end{tabular}

\footnotetext{
${ }^{11}$ Information on mainland Portugal.

${ }^{12}$ Portuguese Classification of Economic Activities (CAE), Revision 3.
} 


\begin{tabular}{|c|c|c|c|c|c|c|c|c|c|c|c|c|}
\hline $\begin{array}{l}\mathrm{H}- \\
\text { Transport \& } \\
\text { storage }\end{array}$ & 43 & 26,189 & 204.2 & 51 & 21,193 & 168 & 62 & 35,519 & 281 & 62 & 31,375 & 265 \\
\hline $\begin{array}{l}\text { I- Hotels, } \\
\text { restaurants } \\
\text { \& related } \\
\text { services }\end{array}$ & 11 & 1,149 & 6.4 & 11 & 850 & 5 & 11 & 1,006 & 6 & 8 & 563 & 3 \\
\hline $\begin{array}{l}\text { J- } \\
\text { Information } \\
\& \\
\text { communicati } \\
\text { ons }\end{array}$ & 4 & 1,534 & 25.2 & 6 & 1,154 & 18 & 12 & 2,195 & 35 & 2 & 886 & 14 \\
\hline $\begin{array}{l}\text { K - Financial } \\
\& \text { insurance } \\
\text { activities }\end{array}$ & 4 & 1,638 & 18.8 & 4 & 3,508 & 41 & 5 & 4,767 & 56 & 1 & 1,644 & 20 \\
\hline $\begin{array}{l}\mathrm{L}-\text { Real } \\
\text { estate }\end{array}$ & 1 & 25 & 1.4 & 1 & 40 & 2 & 2 & 38 & 2 & 1 & 16 & 1 \\
\hline $\begin{array}{l}\text { M-Scientific } \\
\& \text { technical } \\
\text { consultancy }\end{array}$ & 6 & 259 & 2.6 & 6 & 225 & 2 & 10 & 404 & 4 & 4 & 105 & 1 \\
\hline $\begin{array}{l}\mathrm{N} \text { - } \\
\text { Administrati } \\
\text { on and } \\
\text { support } \\
\text { services }\end{array}$ & 9 & 1,935 & 8.1 & 11 & 2,352 & 10 & 9 & 3,194 & 14 & 10 & 1,422 & 7 \\
\hline $\begin{array}{l}\mathrm{P}- \\
\text { Education }\end{array}$ & 5 & 943 & 17 & 2 & 958 & 17 & 4 & 1,333 & 24 & 3 & 379 & 7 \\
\hline $\begin{array}{l}\text { Q - Health \& } \\
\text { social work }\end{array}$ & 7 & 6,949 & 35.7 & 6 & 6,822 & 33 & 13 & 14,342 & 69 & 10 & 17,135 & 82 \\
\hline $\begin{array}{l}\mathrm{R}-\text { Arts, } \\
\text { entertainme } \\
\text { nt \& sport }\end{array}$ & 7 & 437 & 20.9 & 5 & 385 & 19 & 9 & 628 & 30 & 7 & 265 & 13 \\
\hline $\begin{array}{l}\text { S - Other } \\
\text { activities \& } \\
\text { services }\end{array}$ & 9 & 1,939 & 28 & 8 & 1,800 & 26 & 11 & 1,568 & 22 & 5 & 762 & 12 \\
\hline
\end{tabular}

*Salaried workers

Source: GEE/Ministério da Economia (2011, 2012, 2013, 2014).

Finally, it should be emphasised that the information available for strikes from 1986 onwards only includes the private sector. Therefore, taking the aforementioned changes in the sociological composition of trade union members into account and the (recent) high level of labour conflict in the public sector, it may be said that the statistics for strikes are significantly underestimated (Gall, 2012). Although there is no statistical series for strikes in 
the public sector, the piecemeal information made available by the Directorate-General of Public Administration and Employment ${ }^{13}$ for the period 2007-2013 corroborates this.

Taking the year 2007 as an example (Table 3), for which there are records for four strikes covering workers directly and indirectly employed by the state administration, the number of strikers totals 128,578 , more than four times the amount for the entire private sector in the same year. The same exercise may be applied to the later period 2010-2013. Once again, focussing on the information available in Table 3 , it can be seen that the contingent of central government employees is extremely significant, in comparison to the number of workers on strike in the whole of the private sector.

Table 3. Strike Turnout Figures, 2007-2013 - Workers Directly and Indirectly Employed by the State Administration

\begin{tabular}{|c|c|c|c|}
\hline Strike & $\begin{array}{c}\text { Workers } \\
\text { covered }\end{array}$ & $\begin{array}{c}\text { Workers on } \\
\text { strike }\end{array}$ & Percentage \\
\hline 30.05 .07 & 344,876 & 48,103 & 13.95 \\
\hline 12.07 .07 & 200,155 & 1,927 & 0.96 \\
\hline 18.10 .07 & 267,411 & 8,281 & 3.1 \\
\hline 30.11 .07 & 321,049 & 70,267 & 21.89 \\
\hline 14.03 .08 & 353,911 & 29,620 & 8.37 \\
\hline 01.10 .08 & 281,314 & 30,237 & 10.75 \\
\hline 21.11 .08 & 209,452 & 8,404 & 4.01 \\
\hline 04.03 .10 & 419,075 & 61,965 & 14.79 \\
\hline 24.11 .10 & 425,877 & 121,833 & 28.61 \\
\hline 14.11 .12 & 334,436 & 70,072 & 21 \\
\hline 27.07 .13 & 309,961 & 63,536 & 20.5 \\
\hline 08.11 .13 & 292,005 & 67,102 & 23 \\
\hline & & &
\end{tabular}

Source: DGAEP, 2014.

\footnotetext{
${ }^{13}$ On 15 May 2007, the then Minister of Finance and Home Affairs introduced procedures for gathering and publishing information on the strike turnout for workers employed in the central government administration. This was continued under the government formed after the general election of 5 June 2011, then discontinued between 16 March and 12 November 2012, the date when it was resumed by order of the Secretary of State for Public Administration. The available information for the period in question is therefore not exhaustive and only covers direct and indirect central administration (DGAEP, 2014). There is no information for local administration.
} 
This rise in the number of strikes and workers on strike does not, however, correspond to any increasing success in obtaining results. In Table 4, which compiles information on campaigns in terms of the results achieved, it can be seen that the overwhelming majority of demands which led to strikes and were included in the notices of strike were rejected. The year 2012 is particularly indicative since, despite the significant increase in the number of strikes and workers on strike identified above, only $4.6 \%$ of the demands were accepted, 8.6\% partially accepted and $86.7 \%$ rejected. In 2013 the percentage of rejected demands reached the maximum for the period in question, rising to $88.1 \%$. This would appear to corroborate the view expressed by those who went on strike, previously cited in connection with the study by Rebelo and Brites (2012).

Table 4. Demands, by Result 2007-2013

\begin{tabular}{|c|c|c|c|c|c|}
\hline Year & $\mathbf{2 0 0 7}$ & $\mathbf{2 0 1 0}$ & $\mathbf{2 0 1 1}$ & $\mathbf{2 0 1 2}$ & $\mathbf{2 0 1 3}$ \\
\hline Total & 100 & 100 & 100 & 100 & 100 \\
\hline Totally accepted & 9.7 & 10.1 & 3.9 & 4.6 & 2.4 \\
\hline Partially accepted & 18 & 20.3 & 19.4 & 8.6 & 9.5 \\
\hline Rejected & 72.3 & 69.6 & 76.7 & 86.7 & 88.1 \\
\hline
\end{tabular}

Source: GEP/MTSS, 2008; GEE/Ministério da Economia, 2011, 2012, 2013, 2014.

\section{The Case of Saúde 24: A Daring Strike in the Context of Enforced Austerity ${ }^{14}$}

In the 2000s, a series of "improbable mobilisations" by workers in precarious employment, including strikes in the catering sector in France (McDonalds and Pizza Hut) and in Italian call centres (such as Atesia, in Rome, involving thousands of workers), led to important reflections on the role of the classic trade union repertoire (Abdelnour et al., 2009; Boumaza and Pierru, 2007; Choi and Mattoni, 2010; Collovald and Mathieu, 2009; Perrin, 2007). A group of organisations also emerged in Portugal from 2002 onwards, proposing to represent segments of workers in precarious employment and consolidate identities based on

\footnotetext{
${ }^{14}$ For a more detailed analysis of this case study, see Soeiro (2014). The data presented here are the result of research which included the following: direct observation of picketing in January 2014; four in-depth, semistructured interviews with nurses in Porto and Lisbon; an analysis of the contents of the documents produced by the group and published on Facebook, and of the minutes of the plenary session of Parliament held on 24 January 2014 (published in the Official Gazette, $1^{\text {st }}$ series, no. 41) and statements by the Portuguese Nurses' Union.
} 
campaigning and mobilising precarious labour (Andrade, 2011; Estanque and Costa, 2012; Soeiro, 2009; 2012). The experience of the Linha Saúde 24 strike may be seen as an example of resorting to the "strike weapon" in the context of this type of mobilisation, seeking to reinvent the campaign repertoire within a framework of decollectivisation, informalisation, individualisation and recommodification of labour and in circumstances defined by austerity policies. On the basis of this concrete case, it is possible to problematize the strategies of the unions and organisations representing workers in precarious employment and the role played by strikes.

\subsection{What is Linha Saúde 24?}

Linha Saúde 24, which was created in 2006, is a helpline which offers a medical screening, advisory and referral service. It operates under the aegis of the Ministry of Health, and is designed to "respond to the healthcare needs of citizens, contributing towards extending and improving access to services and rationalising the use of existing resources," ${ }^{15}$ by dealing with queries and referring users to the National Health Service if necessary. It is open every day of the year, 24 hours per day, and employs approximately 400 professionals, the vast majority of whom are nurses, who provide an answer service divided between two call centres located in Lisbon and Porto, both about the same size. They work for the company on a system of "green receipts" (receipts issued by self-employed workers), and are considered by the employer to be "service providers," even though they follow timetables set by the management, have supervisors and work in the company's premises.

The importance of experience and in-depth knowledge of the National Health Service (NHS) has meant that the recruitment process values the links which these professionals maintain with NHS institutions. The majority of the nurses-advisors work in state hospitals, in addition to being employed by the Linha to supplement their wages. On average, each nurse works around 18 hours a week, in shifts. However, some work full-time and this is their only source of income. The sociographic profile reveals a group which tends to be young, female and qualified (the minimum qualification for the job is a Bachelor's degree). The great majority have other jobs in addition to this precarious form of employment. Union membership is very low, as is experience of collective action in labour issues.

\footnotetext{
15 Information consulted on 19.02.2014, at http://www.dgs.pt/paginas-de-sistema/saude-de-a-a-z/saude24.aspx?v=b5ef3dfe-6f5f-4ce3-8e86-fabad33830bf.
} 
The government opted to delegate the management of the Linha to a private entity, using the public-private partnership model. The nurses are therefore contracted by Linha Cuidados de Saúde, SA (LCS), a company belonging to the Grupo Caixa Seguros e Saúde, SGPS, SA. The partnership is still effective, although, when it ended in 2011, there was a new public request for tender which was won by a consortium headed by Portugal Telecom (PT). However, the result was annulled by the Court of Auditors, on the grounds that it had not "guaranteed the choice of the best proposal" (Decision No. 1/ 2013 of 8 January). The tender was then awarded to another consortium, once again involving LCS, Optimus and Teleperformance. The main criterion for the award was the lowest price, with this consortium submitting a proposal that reduced the cost of calls by almost half (from $16 €$ to $7 €)$. This then became the reason cited by the company at the beginning of December 2013 for presenting a proposal to make significant cuts of $20 \%$ to $50 \%$ to the wages paid to the nurses-advisors, and it was this decision that triggered the labour dispute, leading workers to resort to strike tactics twice in less than one month.

\subsection{The Two Paths of the Campaign}

The first period of mobilisation involving the nurses at Linha Saúde 24 occurred between the time when they first became aware of the company's proposal to cut wages (at the beginning of December 2013) and the first strike, on 4 January 2014. This period included an initial phase of creating and organising workers' collectives, which developed from a secret Facebook group - "Nurses against 7 euros an hour"16 - to the election, in plenary meetings held in Porto and Lisbon, of two informal workers' committees. After this, the strategy appeared to follow two parallel paths.

On the one hand, there was the route which involved negotiations with the company. This began with the nurses agreeing on a common position and subsequently scheduling a meeting with the management. During the course of this process the first contacts were established with the Portuguese Nurses' Union, which was present at the meeting. Tensions between the informal committees and the union structure were evident, due to differences in their perspectives on the problem, cultures of intervention and the kind of attitude that should be adopted. The position on the legitimacy and relevance of resorting to a strike was central to this debate, with the union disapproving of the stoppage decided by the workers,

\footnotetext{
${ }^{16}$ The title refers to the rate proposed by the management, which signified a cut of 1.75 euros per hour.
} 
given that their employment status made this impossible in legal terms and placed them in an even more vulnerable position.

On the other hand, a second path unfolded involving intensive intervention outside the company, in an attempt to mobilise external resources that could compensate for an internal power relationship which was completely unfavourable to the workers, since they had no recourse to the traditional mechanisms that would provide them with the power to negotiate within the company, such as employment contracts or any other formal mechanism for collective representation. It is against this background that the appeal to the Authority for Working Conditions, press conferences, requests for meetings with the Directorate General for Health, the parliamentary groups, the Ministry of Health and the Ordem dos Enfermeiros (the professional and regulatory body for Portuguese nurses) should be understood. These contacts were developed from mid December 2013 to the end of January 2014, i.e. within the "second phase" of the campaign. This second line of action found a staunch ally in the "Precários Inflexíveis" organisation.

The second phase in the process can therefore be defined as the time in which the company management reacted by dispensing with the "services" of sixteen nurses in an attempt to decapitate the protest movement that had emerged. During this period, the cause of the Linha Saúde 24 workers gained greater public visibility and media coverage and clearly crossed into the political arena, leading to parliamentary debates (on 24 January, there was a vote in parliament on proposed resolutions for the problem), a second stoppage (from 24 to 27 January), statements of positions from the Ordem dos Enfermeiros and the CGTP (both on 27 January), a letter of solidarity signed by various leading figures, and clarifications by the company administration published in the newspapers (on 28 January).

\subsection{From Social Networks to Informal Workers' Committees}

At the beginning of December, the Linha Saúde 24 concessionary company began sending workers an amendment to their service provider contracts which envisaged a wage cut from January 2014 onwards, lowering the rate from $8.75 €$ /hour to $7 € /$ hour, as well as changing the rules for payment of quality hours and night shifts, which could range from $25 \%$ to $100 \%$. Although some workers initially signed the amendment, a group of nurses realised the extent of the cuts and began to contest the proposal. Several others then began to refuse to sign, and it was at this point that one of the nurses decided to create a secret group on 
Facebook, whose contents could only be viewed by members of the group and could not be accessed by the general public. She began inviting colleagues to join the group, which was called "Nurses against 7 euros an hour," and it became the first platform for communication between workers at the two call centres in Lisbon and Porto. This was where the pay scales which showed the real value of the wage reductions in question were shared, an appeal was made not to sign the amendments, and the first actions and plenary meetings that would take place a few days later were planned. Thus, cyberspace enabled the group to overcome the geographical distance between the two call centres, and to begin to organise campaigns against the cuts. It was also on Facebook that leadership of the collective began to be established and the need for face-to-face meetings was identified.

The first of these meetings took place shortly afterwards on 11 December in Lisbon, in a room hired by the group of nurses in office premises; it was attended by around fifty workers who, according to one nurse, "couldn't all fit in the room." The decision to negotiate the hourly rate of pay with the company emerged from this meeting. In addition, this first Lisbon plenary elected the informal workers' committee, composed of four members. It was also decided to reinforce links with the workers in Porto, taking advantage of the fact that one of the nurses in the Lisbon call centre had already worked there, which enabled her to add colleagues from the north to the Facebook group and connect with them. In addition to actions involving the company management, with whom a meeting was requested, the group of nurses at the meeting also decided to contact the Precários Inflexíveis group, in recognition of the public work carried out by this group regarding so-called "fake green receipts" (a system of illegally employing dependent workers as if they were self-employed in order to save costs). As will later be seen, the support of Precários Inflexíveis enabled them to diversify their campaign, and especially to develop a strategy for "winning over public opinion" by getting media coverage for the problem, attempting to gain the sympathy of patients and projecting the nurses' dispute with LCS beyond the confines of the company to ensure that it was discussed in public debates, in the legal field and in the political arena.

\subsection{From the ACT to Meeting the Management}

The first public action of the workers was to lodge a complaint with the Authority for Working Conditions (ACT) to initiate an inspection that would determine the legality of the employment relationship established between the LCS and the nurses. Recognition of this 
employment relationship would become crucial, since the nurses could only activate protection, some forms of collective action and the type of employee-employer negotiations they envisaged within this framework. At the same time, the management was confronted with a joint statement of the position adopted by the workers in the form of a signed letter that contested the contents of the proposed amendment and proposed that the rate paid to nurses should be negotiated with the company. As a consequence of this document, which was signed by approximately 300 workers, the first meeting took place with a representative of the management.

According to the nurses who were interviewed, none of the members of the informal workers' committees had any previous trade union experience. Contact with the Portuguese Nurses' Union was mainly established by the Porto group. Safeguarding their autonomy to direct the campaign was specifically emphasised at this meeting. In the words of one of the workers:

It was clear from the start that it was us who would be negotiating, and he [the union leader] said that he couldn't represent us even if we were unionised because of our employment status $[\ldots]$.

The meeting with the administrator did not produce the desired effects for the nurses. In fact, the company management would henceforth refuse to talk to members of the informal workers' committees, instead preferring to communicate with the union.

The management didn't want to meet with us, only the union, which was supposed to be good because it avoided reprisals. That was when I wanted to create union representatives within the Linha, but the union wouldn't accept that because we were on "green receipts."

This attempt to enter into negotiations with the company was followed by a phase when the committees began to increase their contacts with entities outside the company, seeking to gain support and media coverage for the nurses' cause. Two days after the meeting with the management, they met with the Directorate-General for Health and tried to involve the Ordem dos Enfermeiros in the ongoing labour dispute. In both cases, however, the understanding that this was an "internal" company problem prevailed in the opinion of the institutions that were contacted. For the workers, the relative failure of these meetings did not mean abandoning the strategy of creating visibility for the dispute, and the idea that they could also gain strength from public opinion gained weight within the core leadership. The subsequent strike that was called for the beginning of January resulted from the 
impasse created by these initial approaches. The media coverage and recourse to forms of protest that included "flooding" the line with calls were two important features of this protest.

\subsection{The Two Stoppages and Tensions Involving the Union}

For workers who do not have contracts the question of taking strike action is not a new issue. During the various general strikes, groups of people working on false "green receipts" had, in fact, already problematized the issue of exercising this right in the case of false "service providers." Whilst it is true that the right to strike is recognised in the Constitution and that the law considers it "non-renounceable" and also envisages the possibility of it being mandated by workers' assemblies within a company rather than only by unions, it is also true that, from a legal point of view, a worker whose employment status is considered "independent" is subject to restrictions in terms of formal recognition of this right. In the case of the Linha Saúde 24 nurses, recourse to "stoppages" - a term that recurs in the interviews - was discussed and decided in informal meetings of workers as a response to the inflexibility of the management and as an act of solidarity with their colleagues who had been dismissed. In the words of one of the workers,

On 4 January there were these so-called contracts that ended in January and all the people who did not sign them had their shifts taken away from them, and after that we decided on the first stoppage as a form of protest against the first sackings.

The strike was the big moment in terms of public visibility for the dispute, given the media attention it received. It was the moment when the nurses' campaign clearly spread out into the public arena, obliging the LCS management to respond publicly to the action taken by the workers.

From the outset, relations with the trade union were not devoid of tension. There did not seem to be any agreement on the nature of the employment status, which would lead to the idea that since the nurses were working on "green receipts," they were barred from taking certain forms of action - such as strikes - which the union could not legally authorise. According to one of the workers,

The union was against it [...] because they said that as we were on "green receipts" strikes didn't apply to us and they couldn't call a strike. They could in a hospital, but not with us.

Another worker affirmed: 
[...] We stopped the Linha, despite the union. [...] But the stoppage got lots of coverage, the media in Porto and Lisbon talked about nothing else all day. And then the union wanted visibility, it was there at the end of the day, speaking on television.

There was a good turnout for the first stoppage, totalling around $70 \%$ of the workers at the two call centres, and stronger in Porto than Lisbon. In response to this strike the company reacted by dismissing 16 workers, including those who had led the campaign. A second strike was held in protest at the dismissals on the same day that Parliament rejected two draft resolutions which involved settling the contractual situation of the nurses working at the Linha and public management of the service. Once again, the strike was held without the backing of the union.

These tensions would be exploited by the company management, which refused to meet with the informal workers' committees who were leading the campaign, but still met with the union on various occasions and tried to negotiate different agreements with it. In a clarification published in the newspapers at the end of January, the management not only refused to recognise the stoppage organised by the workers as a strike - it considered it "boycotting LCS activities" - but also made a clear distinction between the union and the committees, stating that the "boycott" had been organised by an "ad hoc committee of nurses formed outside the trade union structure that represents these professionals". ${ }^{17}$

\subsection{From Labour Conflict to Political Conflict}

The transition of the dispute between the nurses and the Linha Saúde 24 management to the political arena gave it greater visibility. By mid December, the informal workers' committee had sent a letter to the parliamentary groups presenting the problem in terms of the possible negative impacts on the "quality of the helpline," emphasising the consequences of the decision, not only for the workers (a pay cut) but also for users of the service (the quality of the service provided), so that the question could be considered as more than a strict employment issue.

The group of nurses was received by the parliamentary groups of the Bloco de Esquerda (BE - Left Bloc), Partido Comunista Português (PCP - Portuguese Communist Party) and Partido Social Democrata (PSD - Social Democratic Party). As a result of these meetings, two

\footnotetext{
${ }^{17}$ LCS, “Linha Saúde 24 - Esclarecimento,” Jornal de Notícias, 30 January 2014.
} 
of the parties presented draft resolutions to Parliament, which were discussed and put to a vote at a plenary session on 24 January 2014.

In the parliamentary debate, the BE and PCP defended their proposals, criticising the company management and arguing that the government should be responsible for introducing employment contracts. The Partido Socialista (PS - Socialist Party) considered that the Ministry of Health should intervene "so that the service is not undermined." The PSD, represented by MP Graça Mota, argued that it was "clearly an employment issue concerning a private company and the professionals who provide it with services," considering that "we should not talk about dependent work, but provision of services in general." The proposals were rejected, with the PS, PCP, BE and the Green Party voting in favour and the PSD and Partido Popular (CDS-PP - People's Party), which supported the government, voting against.

The politicisation of the conflict was viewed ambivalently by the workers, who on the one hand acknowledged its effect in projecting the dispute onto the public arena - "it was certainly useful, it gave us all the visibility we have at the moment" - but on the other considered that their employment struggle had been transformed into a "party political issue," and they were being penalized because the company's managing director was affiliated with PSD.

This broadening of alliances and transformation of the conflict into an "exemplary case" had implications that extended beyond the company and involved more than parliamentary debate. On 28 January a letter was published signed by 33 leading figures, including trade unionists, specialists in labour law, academics, artists and activists in precarious employment. It stated that the firing of the Linha Saúde 24 nurses was "an attack, not only on these workers, but on all citizens, and a threat to democracy, since it violates the right to freedom of expression and organisation," and that it was "imperative to defend democracy and therefore defend those working at Linha Saúde 24."

A few days later, the nurses delivered evidence to the Authority for Working Conditions with the aim of enforcing the Law on Precarious Employment. At the end of February, the findings of the ACT report favoured some of the workers, who proclaimed a victory and instigated legal proceedings, which are still ongoing, for recognition of their rights. 


\section{Conclusion: Is the Strike still a Weapon?}

The case study presented here contains, in essence, some of the most representative trends in the ongoing decline in employment conditions in Portugal. They include the use of subcontracting by the state, a promiscuous link between economic interests and networks of political and party complicity, the use of "false green receipts" as a means of sidestepping the legal provisions for contracting workers, and the spread of precarious employment, namely in highly qualified segments. It is also a significant example due to the fact that it led to protest, rather than resignation. It exemplifies the characteristics of socio-labour struggle undertaken in a context of austerity: the use of new technologies as a platform for meeting and organising; the improvised use of informal representation mechanisms in a context of decollectivisation of labour relations; tensions with the classic trade union repertoires; distancing and a certain mistrust of union intervention; externalisation of the labour dispute, which moved from within the company to the legal, political and media arenas; suppression of the use of strikes as "illegal boycotts."

In making the conditions for exploitation more acute, the "age of austerity" paves the way for the intensification of protest. The example described here illustrates this point, as does the recent decision to create a national union of call centre workers (resulting from a meeting held in Lisbon on 26 April 2014). However, in intensifying precarious employment, austerity also inhibits the use of some of the most significant forms of campaigning in the history of the working class and the trade union movement. A sociology which addresses this paradox should aim to reveal and interpret the emerging forms of social conflict, the unionbased organisation of workers and the use of strikes, mobilising the tools of academic reflection as part of the struggle for dignified employment.

Translated by Sheena Caldwell

Revised by Teresa Tavares

\section{References}

Abdelnour, Sarah; Collovald, Annie; Mathieu, Lilian; Péroumal, Frédéric; Perrin, Evelyne (2009), "Précarité et luttes collectives: renouvellement, refus de la délégation ou décalages d'expériences militantes?" Sociétés Contemporaines, 74: 73-95.

Andrade, Cristina (2011), Organização de trabalhadoras/es em contextos de precarização. Master's Thesis. Porto: University of Porto, Portugal.

Boumaza, Magali; Pierru, Emmanuel (2007), "Des mouvements de précaires à I'unification d'une cause," Sociétés Contemporaines, 65: 7-25. DOI: 10.3917/soco.065.0007 
Bruun, Niklas (2013), "The Right to Strike and the EU," International Union Rights, 20(2): 8-9.

Campos Lima, Maria da Paz; Artiles, Antonio Martin (2011), "Crisis and Trade Union Challenges in Portugal and Spain: Between General Strikes and Social Pacts," Transfer - European Review of Labour and Research, 17(3): 387-402.

Choi, Hae-Lin; Mattoni, Alice (2010), "The Contentious Field of Precarious Work in Italy: Political Actors, Strategies and Coalitions", WorkingUSA: The Journal of Labor and Society, 13: 213-243. DOI: 10.1111/j.1743-4580.2010.00284.x

Collovald, Annie; Mathieu, Lilian (2009), “Mobilisations improbables et apprentissage d'un répertoire syndical," Politix, 2(86): 119-143. DOI: 10.3917/pox.086.0119

Coser, Lewis (1956), The Functions of Social Conflict. New York: The Free Press.

Costa, Hermes Augusto (2008), Sindicalismo global ou metáfora adiada? Discursos e práticas transnacionais da CGTP e da CUT. Porto: Afrontamento.

Costa, Hermes Augusto (2010), “Austeridade europeia, protesto europeu: o valor das manifestações transnacionais," Le Monde Diplomatique (Portuguese edition), September, No. 47, 24.

Costa, Hermes Augusto (2011), "Do enquadramento teórico do sindicalismo às respostas pragmáticas," in Elísio Estanque \& Hermes Augusto Costa (eds.), O sindicalismo português e a nova questão social: crise ou renovação? Coimbra: Almedina, 13-48.

Costa, Hermes Augusto (2012a), "Wage Cuts in the Portuguese Public Sector: The Negative Effects of a Court Decision on Labour Relations," Transfer - European Review of Labour and Research, 18(2): 229-231.

Costa, Hermes Augusto (2012b), "From Europe as a Model to Europe as Austerity: The Impact of the Crisis on Portuguese Trade Unions", Transfer - European Review of Labour and Research, 18(4): 397-410.

Dahrendorf, Ralph (1981), "Elementos para uma teoria do conflito social," in Sociedade e Liberdade. Brasília: Universidade de Brasília, 133-155 [orig. ed.: 1961].

Dias, Hugo (2012), "Greve," in Centro de Estudos Sociais (ed.), Dicionário das crises e das alternativas. Coimbra: Almedina, 113-114.

DGAEP - Direção Geral da Administração e Emprego Público (2014), "Informação sobre as Greves da AP." Accessed on 05.03.2014, at http://www.dgap.gov.pt/index.cfm?OBJID=e61955ea-6194-44bca938-b6dcbbec5902 and http://www.dgap.gov.pt/index.cfm?OBJID=e32c287d-52c1-4b03-b73e$244 \mathrm{ffc} 561 \mathrm{fg} 8$

Estanque, Elísio (2010), "Sociologia da greve," Público newspaper, 24 November, 63.

Estanque, Elísio (2012), A classe média. Ascensão e declínio. Lisbon: Fundação Francisco Manuel dos Santos.

Estanque, Elísio (2013), “O desemprego é uma oportunidade?” in José Soeiro; Nuno Serra; Miguel Cardina (eds.), Não acredite em tudo o que pensa. Lisbon: Tinta da China, 73-84.

Estanque, Elísio; Costa, Hermes Augusto (2012), "Labour Relations and Social Movements," in Denis Erasga (ed.), Sociological Landscape: Theories, Realities and Trends. Rijeka/Croatia: INTECH/Open Access Publishing, 257-282. Accessed on 22.05.2012, at http://www.intechopen.com/articles/show/title/labour-relations-and-social-movements.

Estanque, Elísio; Costa, Hermes Augusto; Soeiro, José (2013), "The New Global Cycle of Protest and the Portuguese Case," Journal of Social Science Education, 12(1): 31-40.

Eurostat (2014), News release, Euro Indicators 17/2013. Accessed on 31.01.2014, at http://epp.eurostat.ec.europa.eu/portal/page/portal/euroindicators/news releases. 
Fernandes, António Monteiro (2012), “Uma estranha decisão," Público newspaper, 20 June, 59.

Ferreira, António Casimiro (2012), Sociedade da austeridade e direito do trabalho de exceção. Lisbon: Vida Económica.

Freire, João (2001), Sociologia do trabalho: uma introdução. Porto: Afrontamento.

GEE - Gabinete de Estratégia e Estudos, Ministério da Economia (2011, 2012, 2013, 2014), Estatísticas em Síntese - Greves Continente. Accessed on 05.05.2015, at http://www.gee.min-economia.pt/.

GEP/MTSS (2008), Séries Cronológicas GREVES 1986 - 2007. Accessed on 05.03.2014, at http://www.gep.msess.gov.pt/estatistica/greves/seriegreves 1986 2007.pdf.

Gall, Gregor (2012), "Quiescence Continued? Recent Strike Activity in Nine Western European Economies," Economic and Industrial Democracy, 34(4): 667-691.

Giraud, Baptiste (2005), "Conditions et dynamiques de la transformation des usages syndicaux de la grève." Paper given at the 8th Congress of the Association Française de Science Politique, at the round table "Où en sont les théories de l'action collective?" 1-17 (mimeo).

Giubboni, Stefano; O'Brien, Charlotte (2009), "The Right to Strike: Fundamental Principle or Fetter?" in ESA (ed.), Full papers, 9th Conference of the European Sociological Association - European Society or European Societies? (Research Network 17, Industrial Relations, Labour Market Institutions and Employment). Lisbon: ISCTE/IUL, 1-18 [CD-Rom].

Gomes, Pedro Botelho (2012), "Uma bomba atómica social?" Público newspaper, 24 June. Accessed on 24.06.2012 at http://www.publico.pt/opiniao/jornal/uma-bomba-atomica-social-24772823.

Hyman, Richard (2012), "Can a Crisis be an Opportunity? The Challenges of Strategy and Democracy." Paper given at the Opening Plenary of the Industrial Relations in Europe Conference (IREC) and the ESA Research Network "Work, Employment and Industrial Relations" (RN 17), held in Lisbon (ISCTE) on 6 September.

ICTWSS (2013), "Database on Institutional Characteristics of Trade Unions, Wage Setting, State Intervention and Social Pacts in 34 countries between 1960 and 2007." Accessed on 05.03.2014, at http://www.uva-aias.net/208.

IUR (2013), “Editorial: A Right we Must Defend," International Union Rights, 20(2): 2.

Leite, Jorge; Costa, Hermes Augusto; Silva, Manuel Carvalho; Almeida, João Ramos (2013), "Austeridade, reformas laborais e desvalorização do trabalho," in Observatório sobre Crises e Alternativas (ed.), A anatomia da crise: identificar os problemas para construir alternativas $\left(1^{\text {st }}\right.$ preliminary report). Coimbra/Lisbon: Observatório sobre Crises e Alternativas, 108-160.

MTSS (2006), Livro Verde sobre as relações laborais. Lisbon: MTSS.

Observatório do Emprego e Formação Profissional, Região Autónoma dos Açores (2009, 2010, 2011, 2012, 2013, 2014), "Estatística de Greves." Accessed on 05.05.2015, at http://www.azores.gov.pt.

OECD (2015), "Trade Union Density" and "Union members and employees." Accessed on 05.05.2015, at https://stats.oecd.org/Index.aspx?DataSetCode=UN DEN.

Olson, Mancur (1965), The Logic of Collective Action: Public Goods and the Theory of Groups. Cambridge, Mass.: Harvard UP.

Ortiz, Isabel; Burke, Sara; Berrada, Mohamed; Cortés, Hernán (2013), "World protests 2006-2013." Initiative for Policy Dialogue and Friedrich-Ebert-Stiftung New York Working Paper 2013. New York: Columbia University/ Friedrich-Ebert-Stiftung.

Pedersini, Roberto (2010), "Trade Union Strategies to Recruit New Groups of Workers," electronic Report. Dublin: Eurofound. Accessed on 05.03.2014, at http://www.eurofound.europa.eu/eiro/studies/tn0901028s/tn0901028s.htm. 
Perrin, E. (2007), "Nouvelles formes d'expression des conflits du travail dans les luttes de précaires," Revue multidisciplinaire sur l'emploi, le syndicalisme et le travail (REMEST), 2(2): 48-64.

Rebelo, Glória (2012), "Tempo e condições de trabalho," Público newspaper, 6 April, 56.

Rebelo, José; Brites, Rui (2012), A comunicação sindical da CGTP-IN. Lisbon: CGTP.

Rosas, Fernando (2012), “Uma Mudança de Paradigma,” Vírus, 1: 10-16.

Santos, Boaventura de Sousa (2004), "Teses para a renovação do sindicalismo em Portugal, seguidas de um apelo," in Elísio Estanque; António Casimiro Ferreira; Hermes Costa; Leonardo Mello e Silva; Roberto Veras (eds.), Relações laborais e sindicalismo em mudança-Portugal, Brasil e o contexto transnacional. Coimbra: Quarteto, 161-180.

Santos, Boaventura de Sousa (2012), Portugal. Ensaio contra a autoflagelação. Coimbra: Almedina.

Secretaria Geral da Educação e Recursos Humanos, Região Autónoma da Madeira (2014), "Greves exclusivamente regionais. Ano 2013." Accessed on 05.03.2014, at http://srrh.govmadeira.pt/Portals/5/Estatistica/Greves\%20regionais Ano\%202013.\%20Word.pdf.

Secretaria Geral da Educação e Recursos Humanos, Região Autónoma da Madeira (2015), "Greves exclusivamente regionais. Ano 2013. Versão Final." Accessed on 05.05.2015, at http://srrh.govmadeira.pt/Portals/5/Estatistica/Greves\%20regionais Ano\%202013-Final.\%20Word.pdf.

Silva, Manuel Carvalho da (2002), Agir contra a corrente: reflexões de um sindicalista. Porto: Campo das Letras.

Silva, Manuel Carvalho da (2012), Vencer o medo - ideias para Portugal. Lisbon: Temas e Debates.

Soeiro, José (2009), "Hipóteses sobre os movimentos de precários em Portugal," in FERVE (ed.), Dois anos a ferver. Retratos da luta, balanço da precariedade. Porto: Afrontamento.

Soeiro, José (2012), "'Perdi o emprego, encontrei uma ocupação'. Juventude, precariedade e o novo ciclo de protesto global," in Giovanni Alves; Elísio Estanque (eds.), Trabalho, juventude $e$ precariedade. Barau, São Paulo: Editorial Praxis.

Soeiro, José (2014), "Geração precária? Trajetórias, vivências, subjetividade colectiva e discurso público sobre a precariedade dos jovens em Portugal." Ongoing PhD research, funded by the Fundação para a Ciência e Tecnologia (SFRH/BD/48470/2008).

Sousa, Henrique José Carvalho (2011), "Sindicalização: a vida por detrás das estatísticas (alguns problemas metodológicos)," Working Paper, Projecto Sociedade Civil e Democracia, FCSH-UNL.

Standing, Guy (2011), The Precariat. The New Dangerous Class. London: Bloomsbury.

Stoleroff, Alan (2013), "A crise e as crises do sindicalismo: há uma revitalização possível?" in Raquel Varela (ed.) A segurança social é sustentável. Trabalho, Estado e segurança social em Portugal. Lisbon: Bertrand, 207-239. 